\title{
Service Learning: Experiences and Perceptions Towards Students in UTM, Malaysia
}

Mohd Syafiq Md Salleh*, Mahani Mokhtar

Department of Educational Foundation and Social Science, Faculty of Education, UTM Johor Bahru, Malaysia.

*Corresponding author: p-mahani@utm.my

\begin{abstract}
The purpose of this phenomenological study was to explore the experiences and perceptions of students who successfully completed their service learning projects in UTM. The qualitative approach was using and four main themes are emerged from the students interview, such as pedagogical aspect, personal benefits, challenges and problems. The findings showed that service learning has great implication and beneficial for students and community and develop soft skills for their career benefits.
\end{abstract}

Keywords: Service learning; community based learning; teaching and learning; education.

(C) 2017 Penerbit UTM Press. All rights reserved

\subsection{INTRODUCTION}

The value of service learning (SL) towards development of softs kills among graduates have caught the attention of Malaysian public universities including Universiti Teknologi Malaysia, Johor Bahru (UTM). Thus, UTM has taken the initiative to implement SL as one of the pedagogical tools since March 2011. Service Learning (SL) is a teaching and learning approach which gives the opportunity to students to extend their services to the community through the impact of knowledge and skills which they have learn't in universities. In addition, SL is an approach which combines academic learning objectives and interpersonal skills. Through SL projects, students will learn the process of serving the target community and the experiences will enhance their attributes. Furthermore, experiences and perceptions in SL projects will give professional advantages in their future career (Eyler et al. 2001: Leimer, Yue, \& Rogulkin, 2009).

The learning process in SL give a lot of advantages to students. Since this approach require students to apply their logical and critical thinking in identifying the problems faced by the community and to find suitable solutions using their skills and knowledge (Mary Prentice \& Gail Robinson, 2010), students will have the chance to practice what they have acquired in classrooms. In addition, SL group work allows their knowledge to evolve as the process is interactive. In addition, according to Prentice \& Robinson (2010), SL program has the advantage of instilling students' interest in learning and able to improve their motivation.

Hence, UTM has been recognized and known as UTM courses and community service starting on 2011/2012 under general courses of University Innovation Cluster. SL in UTM, will give contribution to the students and this paper will emphasize and explore the experiences and perceptions of students who completed succes fully in service learning project. As an improvement in future, students need make an early observation of the problems of the community and aligned to the background academic of the students, in order the meaningful learning will be adapt.

\subsection{SERVICE LEARNING MODEL}

SL allows students to work in groups, in pairs and also individually (Maznah $\mathrm{Hj}$ Ibrahim et al, 2014). Therefore, SL projects are definitely not traditional, passive and one direction learning style. Students are not expected to memorize facts to pass examinations. Hence, students can apply knowledge to new situations (Gibson et al, 2011). Hence, the table 1 below shows four SL models which are applied at Northeastern University Boston, USA namely, Model of Direct Service Learning, Model of Problem Based/Community Based Research, Hybrid Model, Continuous Reflection and Experiential Learning Cycle Model. 
Table 1 SL Model of Northeastern University Boston

\begin{tabular}{|c|l|l|l|l|}
\hline Model & \multicolumn{1}{|c|}{ Direct Service Learning } & $\begin{array}{l}\text { Problem Based/Community } \\
\text { Based Research }\end{array}$ & $\begin{array}{c}\text { Continuos Reflection and } \\
\text { Experiential Learning Cycle }\end{array}$ \\
\hline Descriptions & $\begin{array}{l}\text { Students are involved } \\
\text { directly in the community }\end{array}$ & $\begin{array}{l}\text { Based on research on how to } \\
\text { solve the problems in } \\
\text { community }\end{array}$ & $\begin{array}{l}\text { Students as share } \\
\text { partners }\end{array}$ & $\begin{array}{l}\text { Reflection from students will } \\
\text { evolve for given them } \\
\text { description towards their } \\
\text { experiences }\end{array}$ \\
\hline
\end{tabular}

(source: www.northeastern.edu)

An addition, the characteristic of SL approaches are; (a) given the real-life learning; (b) based on their background academic; (c) served to the community; and (d) given the positive impact to students and community.

\subsection{METHODOLOGY}

This research used qualitative approach and phenomenology design whereby interview sessions were adopted to collect data. Ten respondents who completed their service learning projects were chosen to be interviewed for capture their experiences and perceptions. Appointments were made with ten students to get their reflections on their experiences and perceptions while doing the SL projects. Model of Continuous Reflection and Experiential Learning Cycle from North Eastern University was used as a guideline to analyze the narrative reflections.

\section{Model of Continuous Reflection and Experiential Learning Cycle from North Eastern University}

According to that model, students are need to answer basic questions such as 'what is your experience?', 'what is the significant of the program?', and 'what is the next planning?'. The sharing session with Mr. Ariff Azmi, a Master in Education, student who was the project manager of a SL project conducted at Flat Hijau, Taman Plentong Baru, Masai. The name of the project was "Projek Mari Membaca dan Suka Belajar" and it was conducted on 6 June 2015. Table 2 below was a experiences and perceptions from Mr Azmi Ariff as a project manager.

Table 2 Data on experiences and perceptions of Mr Ariff Azmi using model of continuos reflection and experiential learning cycle

\begin{tabular}{|c|c|}
\hline $\begin{array}{l}\text { 1. What is your } \\
\text { experience? }\end{array}$ & $\begin{array}{l}\text { '...the decision for choosing this location after several meetings with other members. The main factor we chose 'Projek Mari } \\
\text { Membaca dan Suka Belajar", because we wanted to encourage not only children but teenagers to nurture reading culture in } \\
\text { fresh and relax environment in special room that we designed. We put the used books that we collected through donation by } \\
\text { students in UTM, and new books we bought from fund collections we got from NGO's and faculty. That's why, we need to } \\
\text { create a solid objective, because we wanted to make a win-win situation, which is both side will get an advantages. For } \\
\text { examples, the activities that we managed to make are aerobic, storytelling, posters, bookmarks, and reading. When we talk } \\
\text { about challenges, yes, we faced several problem such as fund collecting, dealing with the VIP, community and group } \\
\text { members itself, the catering came late, the presence of the community in earlier hour, but in the middle hour, we manage to } \\
\text { gather them in the program side...' }\end{array}$ \\
\hline $\begin{array}{l}\text { 2. What is the } \\
\text { significant of the } \\
\text { program? }\end{array}$ & $\begin{array}{l}\text {...this SL program is indirectly develop their soft skills through the establishment of their interests with the community. We } \\
\text { felt our responsibility in helping local people in need, without expecting fully help and fund from government in shaping the } \\
\text { development of the local community and our benefit as well. This program are able to receive new knowledge and skills, } \\
\text { develop our potential, challenge ourselves in the process of solving problems, and most importantly, apply the values and } \\
\text { develop soft skills... }\end{array}$ \\
\hline $\begin{array}{l}\text { 3. What is the next } \\
\text { planning? }\end{array}$ & $\begin{array}{l}\text {...for your information this is my first experience to join such program. So, i believed this will give me new experiences and } \\
\text { expectations after joined this program. I believed my other members also are excited to manage and run this kind of program. } \\
\text { We believed, this project will develop our inner and skills for our future career. If i have an opportunity, i will conduct the } \\
\text { same project in future... }\end{array}$ \\
\hline
\end{tabular}

The questions in the table were used to explore the student's experiences and perceptions on the SL project. The last two final step (what is the significant? and what is the next planning?) in this reflection are very important for providing students with significant opportunities they learned from the SL program.

\subsection{RESULTS AND DISCUSSION}

Data from the findings showed that respondents had different experiences and perceptions regarding the service learning project which they had conducted. Overall, the respondents agreed that their SL project was an effective practice in developing their interpersonal skills. However, there were still rooms for improvement since there were some shortcomings in its implementation. Based on the interview data, four themes were obtained from the experiences and perceptions of the respondents in this study. The themes were named as pedagogy aspect, personal benefits, challenges, and problems.

\section{Pedagogy Aspect}

Pedagogy involves research on teaching and learning process. Pedagogy is the study of teaching, especially in formal education. In other words, it is the science and art of how to teach and educate other person. Among the responses provided are as below. 


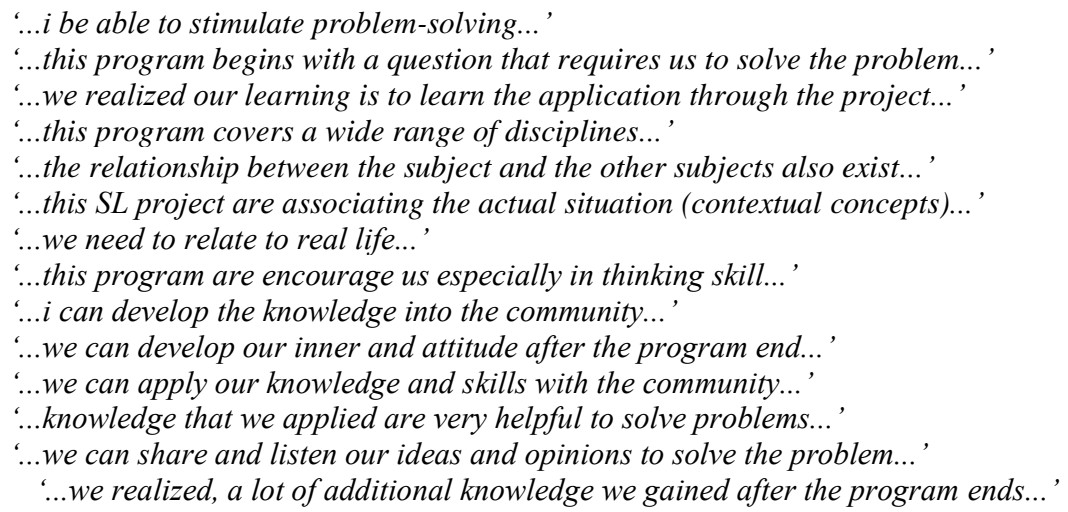

Based on the statements above, the respondents have a very positive view in term of pedagogy aspect and they were able to apply the skills and knowledge learned in classrooms to the community.

\section{Personal Benefits}

Directly, students will received the benefit from the SL program. The person who received the benefit, are able to achieved the goals after they make a reflections. Among the responses provided are as below.

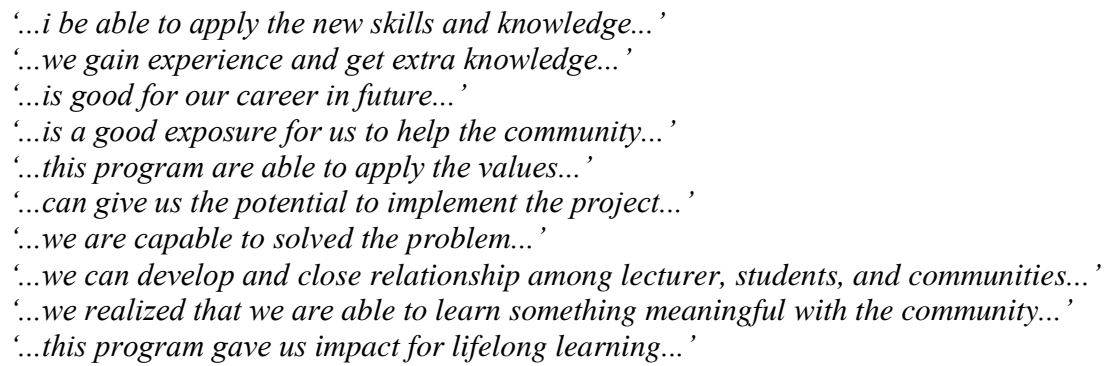

Based on the statements above, the respondents had a very positive view in terms of personal benefits. Interaction among students during the SL project also promoted social skills.

\section{Challenges}

Risk is the challenges that is likely to occur when handling a program. Good risk management can become a pioneer in the discovery of opportunities and new methods in resolving problems or conflicts. Therefore, a risk is not merely a problem that needs to be avoided, but must be faced with intelligence and using effective methods. Among the responses provided are as below.

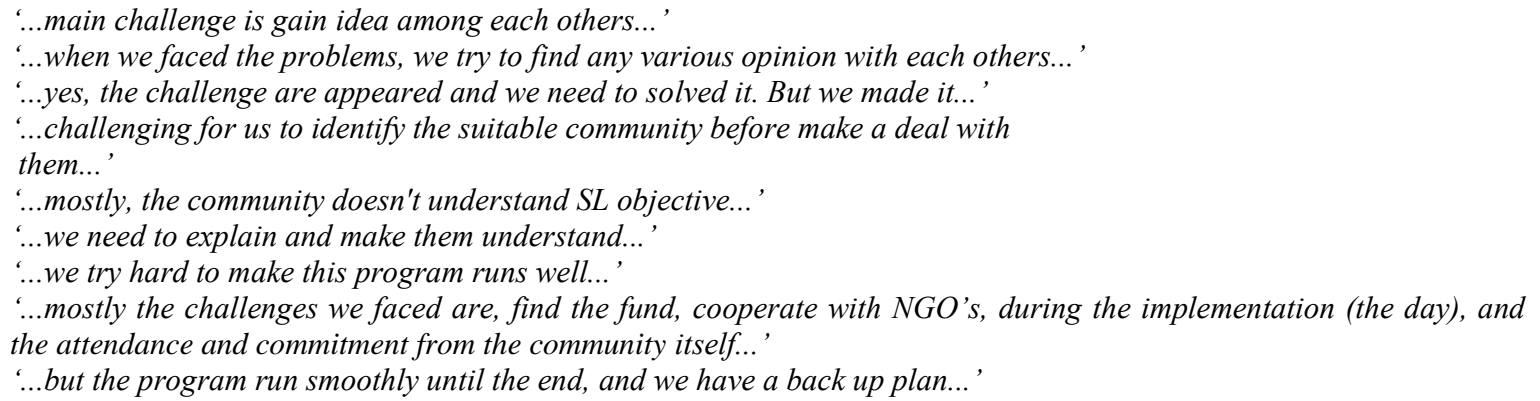

Based on the statements above, the respondents had very positive views in term of the challenges. As we now, the more appearing challenges will make them good in risk management.

Problems

Whenever problems arise, students were required to find solutions and used their capability to settle them. Among the responses provided are as below.

'...we have face a problem in communication to convince the community...' 


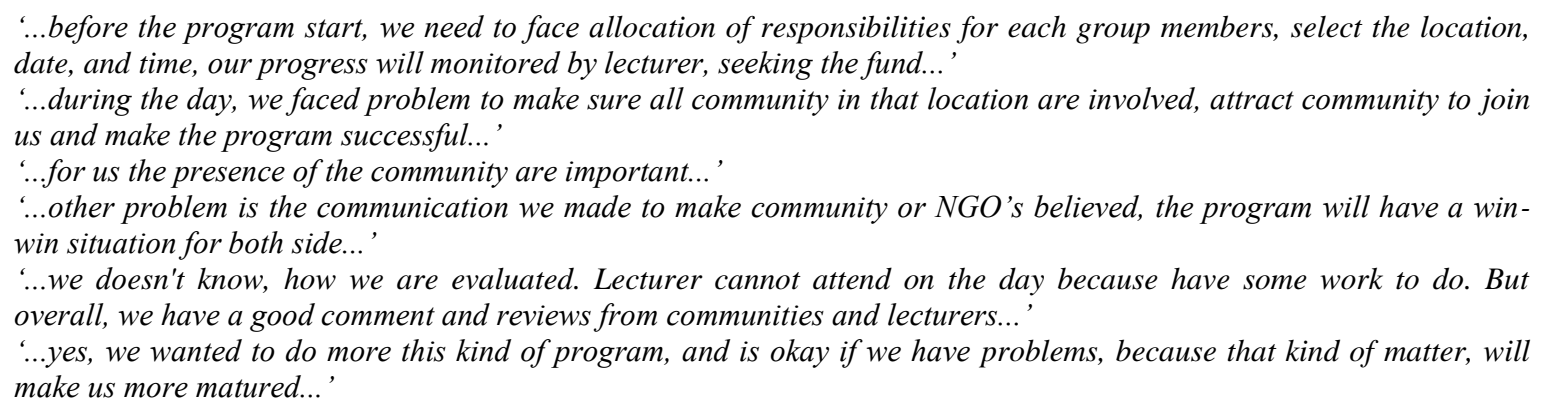

Based on the statements above, the respondents had very positive views in term of the problems aspect. Table 3 below shows the summary of feedback gathered from the respondents.

\subsection{DISCUSSION}

Based on the students experiences and perceptions towards this SL program. It gave students the true meaning of life, especially in pedagogy aspect, personal benefit, challenges, and problems through the service learning project. Students will understand the importance of life and have a positive adjective with the SL program. Students showed interest in implementing this program again in the future, since this is a new program that was introduced to them in performing tasks. Accordingly to the data findings, they agreed, through the SL program they were able to receive new knowledge and skills, develop their potential, challenge themselves in the process of solving problems, and most importantly, apply the values and develop soft skills for their career benefits.

\subsection{CONCLUSION}

Therefore, this program will effect the development of country in future, society and the individual as the form of skilled human capital, especially in the year 2020. Hence, trained manpower is a crucial asset in the progress and development of the country, movement in support of the mission to strengthen the quality of human capital, which has become the core of the National Mission, 2006-2020, namely by increasing the knowledge, creativity and innovation and nurture ' first class mentality'.

\section{References}

Ali Hebert. (2015). Student Learning Through Service Learning: Effects on Academic Development, Civic Responsibility, Interpersonal Skills and Practical Skills. Active Learning in Higher Education, 16(1), 37-49.

Barrie E. Litzky, Veronica M. Godshalk, and Cynthia Walton-Bongers (2009). Social Entrepreneurship and Community Leadership: A Service-Learning Model for Management Education. Journal of Management Education, 34(1), 142-162.

Begley (2014). Service Learning: Integrating Classroom \& Community Goal in North Eastern University Boston. Retrieved from https://www.northeastern.edu/servicelearning/pdfc/Service-.pdf+.

Eyler, J., \& Giles, D. E. (1999). Where's the Learning in Service Learning? San Francisco: Jossey-Bass.

Gibson M et al. (2011). Reflective Practice in Service Learning: Possibilities and Limitations. Education and Training, 53(4), 284-296.

Leimer, C., Yue, H., \& Rogulkin, D. (2009). Does Service Learning Help Students Succeed? Assessing the Effects of Service Learning in California State University. Institutional Research, Assessment and Planning, 1-18.

Prentice, M. \& Robinson, G. (2010). Improving Student Learning Outcomes with Service Learning. Washington: American Association of Community Colleges.

Mohd Fathi Adnan, Azlan Abd Latif, Shahrin Hasim, \& Noor Syafafwati Mamat (2013). Impak Kursus UTM dan Khidmat Komuniti Terhadap Pembangunan Kemahiran Insaniah Pelajar Universiti Teknologi Malaysia. $2^{\text {nd }}$ International Seminar on Quality and Affordable Education 2013 Proceeding, $406-410$.

Maznah Hj Ibrahim (2014). Educating the Educators: Reflections Post SL Projects. National Action Research Conference. 24-25 June 2014. 